\title{
Editorial
}

\section{Socio-Environmental Vulnerability Assessment for Sustainable Management}

\author{
Szymon Szewrański *(i) and Jan K. Kazak (1) \\ Institute of Spatial Management, Wrocław University of Environmental and Life Sciences, ul. Grunwaldzka 55, \\ 50-357 Wrocław, Poland; jan.kazak@upwr.edu.pl \\ * Correspondence: szymon.szewranski@upwr.edu.pl
}

Received: 15 September 2020; Accepted: 18 September 2020; Published: 24 September 2020

Research on complex socio-environmental systems (also known as socio-ecological systems) has a long tradition in scientific considerations. Their theoretical basis was defined already in the 1970s [1]. In the following decades, the concept of a holistic consideration of complex interactions between social, economic, and environmental systems became permanently embedded in the paradigm of sustainable development. In the 21st century, in the face of global challenges faced by human civilization, it was necessary to develop new study areas in the context of research on social and environmental systems. Such concepts as resilience, integrated assessment of ecosystem services, socio-ecological system frameworks, coupled human and natural systems, and vulnerability frameworks appeared [2].

The conceptual framework that considers the vulnerability of complex human-environment systems proposed by Turner et al. (2003) is a rapidly developing research perspective [3]. In the context of the latest research, it has become crucial to seek answers to the question of who or what is most vulnerable to global environmental changes and where this vulnerability is the most crucial in terms of the geo-spatial point of view. Research conducted all over the world indicates that vulnerability to change is not a simple function of exposure to hazards, but also depends on the sensitivity and resilience of complex systems at a particular place and time [4].

Ongoing parallel processes of urbanization, aging of society, population growth, and increasing consumption interplay with threats caused by climate change, extreme weather events, and depletion of resources. As climate-related hazards impact both human and environmental elements, there is a need to explore, analyze, and understand the vulnerability of socio-environmental systems. Therefore, adaptation to climate change as well as sustainable development required a knowledge-based approach and intelligent solutions for integrated assessment of the state of the environment and society. With the purpose of illustrating the dynamics of research on the vulnerability of socio-environmental systems, we have conducted a query of the term "socio-environmental vulnerability" in the Web of Science and Scopus databases. Since 2006, we have observed a gradual increase in interest in the problem of socio-environmental vulnerability. In recent years, on average, six to eight works indexed in databases have appeared annually (Figure 1). Finally, we identified 53 articles in Web of Science and 57 in the Scopus database.

According to the classification of research areas in Web of Science, the largest number of works had been assigned to Environmental Sciences (and Studies) (30\%), Geography (25\%) and Public, Environmental, and Occupational Health (19\%). A total of $11 \%$ of the papers were in the field of Green and Sustainable Science and Technology and 8\% in Education Research. Some articles (4\%) had been tagged as Biodiversity Conservation, Economics, Law, Social Sciences, Interdisciplinary, and Urban Studies. Regarding the Scopus classification, Social Sciences covered $58 \%$ of the papers. In Environmental Science, it was $47 \%$, while in Medicine, it was about $25 \%$. Some papers had been assigned to Agricultural and Biological Sciences (14\%), Earth and Planetary Sciences, or Energy (11\%). In the field of Business, Management, and Accounting, there were $9 \%$ of the publications. Decision 
Sciences covered 5\%, and Arts and Humanities covered 4\%. Among all records, 5\% were recognized as Engineering.

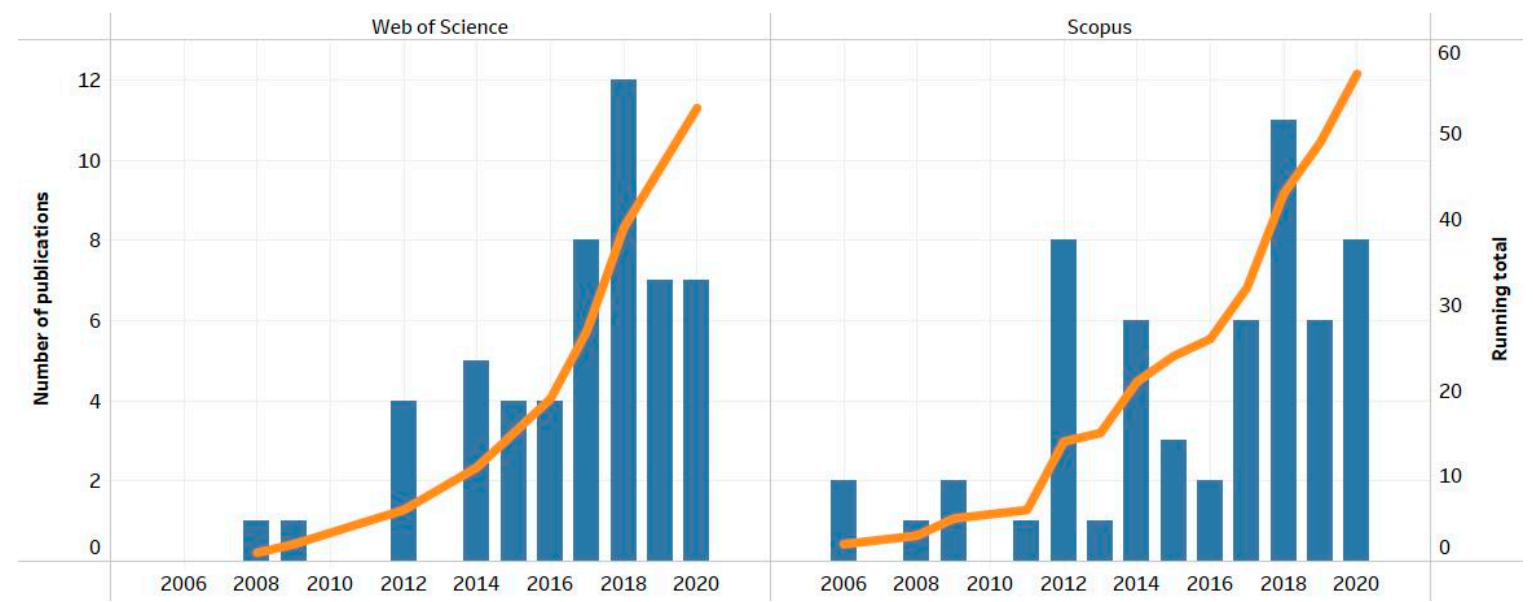

Figure 1. The annual and the running total numbers of scientific publications tagged literally with "socio-environmental vulnerability" in Web of Science and Scopus databases.

The interdisciplinary research conducted in this domain addresses such issues as evaluation of the quality of life in urban and suburban environments [5,6], issues related to public health protection [7,8], environmental injustice [9], engineering and infrastructure safety [10-12], energy security [13], income and environmental risk [14,15], hydrological and climate change risks [16-18], and mapping techniques [19-22]. All of them had been incorporated into socio-environmental vulnerability assessments, which present a broad perspective of this domain.

This Special Issue also explores cross-disciplinary approaches, methodologies, and applications of socio-environmental vulnerability assessments that can be incorporated into sustainable management. The volume collects 20 different points of view, which cover environmental protection and development, urban planning, geography, public policymaking, participation processes, and other cross-disciplinary fields (Figure 2).

Figure 2. Word cloud generated from 20 publications collected in the Special Issue on "Socio-Environmental Vulnerability Assessment for Sustainable Management" in Sustainability. 
The articles collected in this volume come from all over the world and seek answers to multidimensional questions.

- What is the current state of the world's environmental and social systems in local, regional, and national terms [23-25]?

- How can the resilience of environmental and social systems to changing climate or hydrological threats be assessed? Multidimensional and multi-factorial issues require new approaches and analytical tools. Hierarchical methods, clustering, and ranks have been successfully tested by the authors whose work is included in this volume [26-29].

- How does one implement sustainable development in practice? How can the principles of social participation and partnership support modernization processes [30,31]? Is it possible to formulate a progressive environmental and development policy [32]?

- What is the future of social-environmental systems? How will demographic change, particularly in an aging society, affect social and environmental resilience [33]? How should we supply ourselves with energy [34-36]? How should we shape our transport systems [37]? How can technical infrastructure and spatial management support the development of tourism in environmentally valuable areas [38]? Can we leverage our efforts by applying nature-based solutions [39,40]? How can open data and artificial intelligence support us [41,42]?

These and other questions will be answered in this Special Issue. We hope that dissemination of this broad spectrum to the scientific community will be helpful and may possibly open new horizons for future research.

Acknowledgments: The work has been created as a result of scientific activity conducted within the Leading Research Group: Sustainable Cities and Regions at the Wrocław University of Environmental and Life Sciences.

Conflicts of Interest: The authors declare no conflict of interest.

\section{References}

1. Holling, C.S. Resilience and Stability of Ecological Systems. Annu. Rev. Ecol. Syst. 1973, 4, 1-23. [CrossRef]

2. Pulver, S.; Ulibarri, N.; Sobocinski, K.L.; Alexander, S.M.; Johnson, M.L.; McCord, P.F.; Dell'angelo, J. Frontiers in socio-environmental research: Components, connections, scale, and context. Ecol. Soc. 2018, 23. [CrossRef]

3. Turner, B.L.; Kasperson, R.E.; Matsone, P.A.; McCarthy, J.J.; Corell, R.W.; Christensene, L.; Eckley, N.; Kasperson, J.X.; Luers, A.; Martello, M.L.; et al. A framework for vulnerability analysis in sustainability science. Proc. Natl. Acad. Sci. USA 2003, 100, 8074-8079. [CrossRef] [PubMed]

4. Turner, B.L.; Esler, K.J.; Bridgewater, P.; Tewksbury, J.; Sitas, J.N.; Abrahams, B.; Chapin, F.S.; Chowdhury, R.R.; Christie, P.; Diaz, S.; et al. Socio-Environmental Systems (SES) Research: What have we learned and how can we use this information in future research programs. Curr. Opin. Environ. Sustain. 2016, 19, 160-168. [CrossRef]

5. Roggero, M.A.; Ziglio, L.; Miranda, M. Socio-environmental vulnerability, analysis of health situation and indicators: Implications for the quality of life in the city of Sao Paulo. Confin. Fr. Geogr. Fr. Geogr. 2018, 36, 17. [CrossRef]

6. Kran, F.; Ferreira, F.P.M. Life quality in Palmas-To: An analysis through housing and urban environmental indicators. Ambient. Soc. 2006, 9, 123-141. [CrossRef]

7. Londe, L.R.; Marchezini, V.; da Conceição, R.S.; Bortoletto, K.C.; Silva, A.E.P.; dos Santos, E.V.; Reani, R.T. Impacts of socio-environmental disasters on public health: Studies of scenarios in the Brazilian states of Santa Catarina in 2008 and Pernambuco in 2010. Rev. Bras. Estud. Popul. 2015, 32, 537-562. [CrossRef]

8. Houghton, A.; Prudent, N.; Scott, J.E.; Wade, R.; Luber, G. Climate change-related vulnerabilities and local environmental public health tracking through GEMSS: A web-based visualization tool. Appl. Geogr. 2012, 33, 36-44. [CrossRef]

9. de Mendonca, M.B.; da-Silva-Rosa, T.; Monteiro, T.G.; de Souza Matos, R. Improving Disaster Risk Reduction and Resilience Cultures Through Environmental Education: A Case Study in Rio de Janeiro State, Brazil. In Climate Change and Health; Springer: Cham, Switzerland, 2016; pp. 279-295. 
10. Silva, R.T. Integration of hydraulic infrastructure in metropolitan São Paulo. Prospects of change in a context of growing vulnerability. Geogr. Helv. 2011, 66, 92-99. [CrossRef]

11. Zanetti, V.B.; Junior, W.C.S.; De Freitas, D.M. A climate change vulnerability index and case study in a Brazilian Coastal City. Sustainability 2016, 8, 811. [CrossRef]

12. Goncalves, K.D.; Siqueira, A.S.P.; de Castro, H.A.; Hacon, S.D.S.; Gonçalves, K.S.; Siqueira, A.S.P.; de Castro, H.A.; Hacon, S.D.S. Indicator of socio-environmental vulnerability in the Western Amazon. The case of the city of Porto Velho, State of Rondonia, Brazil. Cienc. Saude Coletiva 2014, 19, 3809-3817. [CrossRef]

13. Westin, F.F.; dos Santos, M.A.; Martins, I.D. Hydropower expansion and analysis of the use of strategic and integrated environmental assessment tools in Brazil. Renew. Sustain. Energy Rev. 2014, 37, 750-761. [CrossRef]

14. Castillo-Oropeza, O.A.; Delgado-Hernández, E.; García-Morales, Á. Gentrification and disaster in La Condesa Zone. Bitacora Urbano Territ. 2018, 28, 35-43. [CrossRef]

15. Szewrański, S.; Świąder, M.; Kazak, J.K.; Tokarczyk-Dorociak, K.; van Hoof, J. Socio-Environmental Vulnerability Mapping for Environmental and Flood Resilience Assessment: The Case of Ageing and Poverty in the City of Wrocław, Poland. Integr. Environ. Assess. Manag. 2018, 14, 592-597. [CrossRef] [PubMed]

16. Barros, M.V.F.; Mendes, C.; de Castro, P.H.M. Social-environmental vulnerability to floods in urban areas of Londrina city-PR. Confin. Fr. Geogr. Fr. Geogr. 2015, 24, 21. [CrossRef]

17. Castro, B.; Filho, W.L.; Caetano, F.J.P.; Azeiteiro, U.M. Climate Change and Integrated Coastal Management: Risk Perception and Vulnerability in the Luanda Municipality (Angola). In Climate Change Impacts and Adaptation Strategies for Coastal Communities; Springer: Cham, Switzerland, 2018; pp. 409-426.

18. Claeys, C.; Giuliano, J.; Tepongning Megnifo, H.; Fissier, L.; Rouadjia, A.; Lizée, C.; Geneys, C.; Marçot, N. Interdisciplinary analysis of socio-environmental vulnerabilities: Urbanized cliffs on the Mediterranean coastline. Nat. Sci. Soc. 2017, 25, 241-254. [CrossRef]

19. Johnson, F.A.; Hutton, C.W.; Clarke, M.J. The Socio-Environmental Vulnerability Assessment Approach to Mapping Vulnerability to Climate. In Solutions to Climate Change Challenges in the Built Environment; GeoData Institute, School of Geography, University of Southampton Highfield: Southampton, UK, 2012; pp. 283-301.

20. Mavromatidi, A.; Briche, E.; Claeys, C. Mapping and analyzing socio-environmental vulnerability to coastal hazards induced by climate change: An application to coastal Mediterranean cities in France. Cities 2018, 72, 189-200. [CrossRef]

21. Norman, L.M.; Villarreal, M.L.; Lara-Valencia, F.; Yuan, Y.; Nie, W.; Wilson, S.; Amaya, G.; Sleeter, R. Mapping socio-environmentally vulnerable populations access and exposure to ecosystem services at the U.S.-Mexico borderlands. Appl. Geogr. 2012, 34, 413-424. [CrossRef]

22. Ho, H.C.; Lau, K.K.-L.; Yu, R.; Wang, D.; Woo, J.; Kwok, T.C.Y.; Ng, E. Spatial variability of geriatric depression risk in a high-density city: A data-driven socio-environmental vulnerability mapping approach. Int. J. Environ. Res. Public Health 2017, 14, 994. [CrossRef]

23. Ponomarenko, T.; Nevskaya, M.; Marinina, O. An assessment of the applicability of sustainability measurement tools to resource-based economies of the commonwealth of independent states. Sustainability 2020, 12, 5582. [CrossRef]

24. Nyairo, R.; Machimura, T.; Matsui, T. A combined analysis of sociological and farm management factors affecting household livelihood vulnerability to climate change in rural burundi. Sustainability 2020, 12, 4296. [CrossRef]

25. Derlukiewicz, N.; Mempel-Śniezyk, A.; Mankowska, D.; Dyjakon, A.; Minta, S.; Pilawka, T. How do clusters foster sustainable development? An analysis of EU policies. Sustainability 2020, 12, 1297. [CrossRef]

26. Chaudhary, S.; Wang, Y.; Dixit, A.M.; Khanal, N.R.; Xu, P.; Yan, K.; Liu, Q.; Lu, Y.; Li, M. Eco-environmental risk evaluation for land use planning in areas of potential farmland abandonment in the high mountains of Nepal Himalayas. Sustainability 2019, 11, 6931. [CrossRef]

27. Dumieński, G.; Mruklik, A.; Tiukało, A.; Bedryj, M. The Comparative analysis of the adaptability level of municipalities in the nysa klodzka sub-basin to flood hazard. Sustainability 2020, 12, 3003. [CrossRef]

28. Li, R.; Han, R.; Yu, Q.; Qi, S.; Guo, L. Spatial heterogeneous of ecological vulnerability in arid and semi-arid area: A case of the Ningxia Hui autonomous region, China. Sustainability 2020, 12, 4401. [CrossRef]

29. Long, J.W.; Steel, E.A. Shifting perspectives in assessing socio-environmental vulnerability. Sustainability 2020, 12, 2625. [CrossRef] 
30. Furmankiewicz, M.; Campbell, A. From single-use community facilities support to integrated sustainable development: The aims of inter-municipal cooperation in Poland, 1990-2018. Sustainability 2019, 11, 5890. [CrossRef]

31. Hsu, C.H.; Lin, H.H.; Jhang, S. Sustainable tourism development in protected areas of rivers and water sources: A case study of Jiuqu Stream in China. Sustainability 2020, 12, 5262. [CrossRef]

32. Akbar, I.; Yang, Z.; Han, F.; Kanat, G. The influence of negative political environment on sustainable tourism: A study of Aksu-Jabagly world heritage site, Kazakhstan. Sustainability 2020, 12, 143. [CrossRef]

33. Sobczak, E.; Bartniczak, B.; Raszkowski, A. Aging society and the selected aspects of environmental threats: Evidence from Poland. Sustainability 2020, 12, 4648. [CrossRef]

34. Besser, A.; Kazak, J.K.; Świader, M.; Szewrański, S. A customized decision support system for renewable energy application by housing association. Sustainability 2019, 11, 4377. [CrossRef]

35. Greinert, A.; Mrówczyńska, M.; Szefner, W. The use of waste biomass from thewood industry and municipal sources for energy production. Sustainability 2019, 11, 3083. [CrossRef]

36. Adynkiewicz-Piragas, M.; Miszuk, B. Risk analysis related to impact of climate change on water resources and hydropower production in the Lusatian Neisse River Basin. Sustainability 2020, 12, 5060. [CrossRef]

37. Jaszczak, A.; Morawiak, A.; Zukowska, J. Cycling as a sustainable transport alternative in polish cittaslow towns. Sustainability 2020, 12, 5049. [CrossRef]

38. Kulczyk-Dynowska, A.; Stacherzak, A. Selected elements of technical infrastructure in municipalities territorially connected with national parks. Sustainability 2020, 12, 4015. [CrossRef]

39. Pardela, Ł.; Kowalczyk, T.; Bogacz, A.; Kasowska, D. Sustainable green roof ecosystems: 100 years of functioning on fortifications-A case study. Sustainability 2020, 12, 4721. [CrossRef]

40. Peczkowski, G.; Szawernoga, K.; Kowalczyk, T.; Orzepowski, W.; Pokładek, R. Runoff and water quality in the aspect of environmental impact assessment of experimental area of green roofs in Lower Silesia. Sustainability 2020, 12, 4793. [CrossRef]

41. Czernecki, B.; Glogowski, A.; Nowosad, J. Climate: An R package to access free in-situ meteorological and hydrological datasets for environmental assessment. Sustainability 2020, 12, 394. [CrossRef]

42. Mrówczyńska, M.; Sztubecka, M.; Skiba, M.; Bazan-Krzywoszańska, A.; Bejga, P. The use of artificial intelligence as a tool supporting sustainable development local policy. Sustainability 2019, 11, 4199. [CrossRef]

(C) 2020 by the authors. Licensee MDPI, Basel, Switzerland. This article is an open access article distributed under the terms and conditions of the Creative Commons Attribution (CC BY) license (http://creativecommons.org/licenses/by/4.0/). 